EPJ Web of Conferences 33, 03006 (2012)

DOI: $10.1051 /$ epjconf/20123303006

(C) Owned by the authors, published by EDP Sciences, 2012

\title{
Shale Gas in Europe: pragmatic perspectives and actions
}

\author{
A. Hübner ${ }^{1, a}$, B. Horsfield ${ }^{1}$, and I. Kapp ${ }^{1}$ \\ ${ }^{1}$ GFZ German Research Centre for Geosciences, Telegrafenberg, 14473 Potsdam, Germany
}

\begin{abstract}
Natural gas will continue to play a key role in the EU's energy mix in the coming years, with unconventional gas' role increasing in importance as new resources are exploited worldwide. As far as Europe's own shale gas resources are concerned, it is especially the public's perception and level of acceptance that will make or break shale gas in the near-term. Both the pros and cons need to be discussed based on factual argument rather than speculation. Research organizations such as ours (GFZ German Research Centre for Geosciences) have an active and defining role to play in remedying this deficiency. As far as science and technology developments are concerned, the project "Gas Shales in Europe" (GASH) and the shale gas activities of "GeoEnergie" (GeoEn) are the first major initiatives in Europe focussed on shale gas. Basic and applied geoscientific research is conducted to understand the fundamental nature and interdependencies of the processes leading to shale gas formation. When it comes to knowledge transfer, the perceived and real risks associated with shale gas exploitation need immediate evaluation in Europe using scientific analysis. To proactively target these issues, the GFZ and partners are launching the European Sustainable Operating Practices (E-SOP) Initiative for Unconventional Resources. The web-based Shale Gas Information Platform (SHIP) brings these issues into the public domain.
\end{abstract}

\section{Introduction}

Despite the upcoming shift in energy sources towards the environmentally friendly and renewable, fossil fuels are the current main energy source worldwide, accounting for over $75 \%$ of the total energy budget. And according to major energy projections a diverse energy mix including fossil fuels will remain in force for the foreseeable future [1,2]. Natural gas will continue to play a key role in the EU's energy mix in the coming years [3], with unconventional gas' role increasing in importance as new resources are exploited worldwide.

Risked global gas-in-place estimates have recently been revised upwards to 25,300 Trillion cubic feet [4], significantly outstripping conventional proven natural gas reserve estimates. As far as Europe's own shale gas resources are concerned, scientific and technological innovations will play key roles in defining the dimension of future shale gas production. At the same time, public's perception and level of acceptance play an increasing role for shale gas developments in the nearterm.

\footnotetext{
a e-mail : huebner@gfz-potsdam.de
} 
Due to its low carbon footprint compared with other fossil fuels, and its flexible availability, natural gas is widely regarded as the most important bridge to future renewable energy. Natural gas resources from shales seem to be huge, but the extraction process, including hydraulic fracturing, has caused a debate whether production may be ecologically acceptable or not.

\subsection{Benefits and Risks}

A positive greenhouse gas balance, with natural gas replacing coal and oil as energy fuel, is one of the benefits of shale gas, given that operators use available best technology (eg. now prescribed by U.S. EPA for U.S. hydraulically fractured natural gas wells from 2015 onwards [5]). Moreover, exploiting a domestic energy resource improves energy supply security; increased taxes and new jobs have also been generated in countries where shale gas is produced on a large scale (U.S. and Canada).

Concurrently, discussion about the environmental impact of shale gas production is ongoing and opinions on environmental risks, such as groundwater pollution or seismic activity, diverge strongly. The industry claims that the risks are minor and controllable, while environmental groups often claim the opposite. Biased descriptions of risks can be observed on both sides of the spectrum.

\section{SCIENCE AND TECHNOLOGY}

Until now research on European black shales focused on "conventional" source rock properties, and many shale gas relevant questions concerning properties like adsorption, porosity, permeability, brittleness, etc. were left open. The interest in European licences to explore for shale gas, thus go hand in hand with an interest in basic shale gas research. Several projects initiated and coordinated by the GFZ German Research Centre for Geosciences therefore focus on shale gas and may serve as entry points for the understanding of general features for efficient shale gas production, not only in Europe. The integrated research on European shale gas started by launching the prominent Gas Shales in Europe project (GASH) in 2009 and slightly earlier in 2008 the "GeoEnergie" project (GeoEn).

\subsection{GASH - GAS SHALES IN EUROPE}

The industry funded GASH project (http://www.gas-shales.org) is the first interdisciplinary shale gas research initiative in Europe, and includes research and database development. GFZ's research partners are the leading academic institutions in geosciences from across Europe (e.g., Institut Français du Pétrole, France; TNO, The Netherlands; Universities of Aachen, Clausthal, Germany and Newcastle, GB; GEUS, Denmark and others). The current ten sponsors are BayernGas, ExxonMobil, Gaz de France Suez, Marathon Oil, Repsol, Schlumberger, Statoil, Total, Vermilion Energy, and Wintershall AG. The companies do not act as sponsors alone. Both the companies and scientific partners support GASH by delivering access to core and data material, or by provision and application of their own analytical facilities.

GASH focusses on two aspects: development of a European black shale database and basic research. One main gap in European shale gas exploration is the access to shale gas relevant data from promising stratigraphic horizons crossing national borders. To overcome this issue, a webserviced GIS database is being developed (European Black Shale Data Base, EBSD). The digital framework will allow assessment of distribution of shales, their regional sedimentary facies and paleogeographic/tectonic context (as maps), as well as well and outcrop locations and attributes. Key attributes to be stored in the database include, e.g., depth, thickness, TOC contents, organic matter type, thermal maturity data, gas shows and kicks, geochemistry analysis results, and sedimentary 
facies. The database will include data from 32 European countries. The data are compiled and provided by the participating national geological surveys.

Basic research projects are working on different scales from nanometre to basin range. The scientific approach of analytically oriented subprojects requires core material from well-defined natural laboratories, and includes the Cambro-Ordovician Alum Shale from North Europe, the Lower Jurassic Posidonia Shale from Northern Germany, and Lower Carboniferous black shales from northern Germany and The Netherlands. As most accessible core material for laboratory analyses is mainly from wells drilled years or even decades ago, GASH faces the strong need for fresh core material to determine meaningful physical and chemical properties. Accordingly, GASH drilled the older Palaeozoic Alum Shale on the island of Bornholm (Baltic Sea) in 2010. The next planned well targets the Lower Jurassic Posidonia Shale in northern Germany. In parallel, core material from successful U.S. gas shales (Barnett, Haynesville) is being analysed for comparison.

The topics of the subprojects on reservoir scale (from nanometre to metre) cover geomechanical, physical, chemical and microbiological aspects, all of which are being interpreted in a holistic approach. The overall goals are to determine gas-in-place and producibility, and to unravel quantitatively the influencing factors. Methodologically, the masses, volumes and physical state of gas and oil generated throughout thermal evolution are analysed in order to unravel the relationship between kerogen structure, gas retention and maturation level. TOC/Rock-Eval and pyrolysis methods are used to assess organic content (including total sorbed and free gas), source rock potential, maturity, degree of kerogen transformation, identify heterogeneity and to perform a mass balance of generation and expulsion. Insights into the gas forming processes, including biogenic gas formation, are coupled to a better understanding of pore forming processes (with a focus on nanometre-sized pores), fluid flow and sorption for both the organic and inorganic matrix to unravel the gas storage capacity. In addition, geomechanical experiments complete the methodological chain and deliver data regarding the mechanical and hydraulic heterogeneities of the matrix, but also of fracture integrity. Analysis of fluid inclusions in fracture cements allow to trace and unravel the origin of the gas in time and space.

Additional subprojects focus on features on a basin scale. Basin modelling studies have been carried out on selected European basins which host the natural laboratories (e.g., Lower Saxony Basin and The West Nederland Basin). It is the aim to determine the timing of gas formation in connection to heat flow, pore forming processes and petrophysical properties. These studies are supported by analogue studies of shale gas hosting basins in the U.S. (e.g., Williston Basin and Fort Worth Basin) for the calibration of property development. In addition, the spatial occurrence and characteristics of proven black shales in the subsurface is visualized by seismic and magnetotelluric methods. Field campaigns have been carried out to seismically detect the Cambro-Ordiovician Alum Shale on Bornholm Island and to characterize the Lower Jurassic Posidonia Shale in northern Germany by magnetotellurics.

\subsection{GEOENERGIE - GEOEN}

The GeoEn project (http://www.geoen.de) is funded by the German ministry of research and education (BMBF). Basic research focusses on sedimentology and diagenesis, geomechanics, basin modeling, gas potential and gas ad-/desorption of organic matter of TOC-rich Carboniferous strata in the Northeast German basin, among others.

One question investigated is whether East Germany hosts a significant shale gas potential, and if so, in which rocks and at which depths it occurs? Three sub-projects of GeoEn try to answer these questions and focussed in a first phase on the federal states Saxony-Anhalt, Mecklenburg-West Pomerania, and Brandenburg. The sub-projects take advantage of cored rock samples from deep 
research wells drilled during GDR times, which are available today for research purposes from the state's geological surveys. In a later stage of the project, samples from the state North-Rhine Westphalia were included in the research scheme.

The presence of very small pores, so called „nanopores” in the reservoir rocks are important for the production of natural gas from shales. This type of pores is present eg. in the productive areas of the Barnett shale in Texas [6]. Within the GeoEn project it was proven for the first time that these pores do occur only in thermally generated solid bitumen [7]. It was found that the more nanopores are present the permeability and thus the gas flow is increased. But also the rock matrix may conserve pore spaces, eg. within pyrite crystals. The second phase of GeoEn now addresses also environmentally oriented questions concerning shale gas extraction (see sec. 3 ).

\subsection{EUROPEAN SUSTAINABLE OPERATING PRACTICES (E-SOP) INITIATIVE}

The E-SOP Initiative is a research collaboration of unconventional gas researchers, academia, industry players, government, and other stakeholders in Europe with the intention of identifying, developing, demonstrating, and deploying sustainable field operating practices, safety standards, and environmental assurance. The initiative is led by the Gas Technology Institute GTI (Des Plaines, Illinois) and GFZ German Research Centre for Geosciences in partnership with Environmentally Friendly Drilling program (EFD) Europe.

Specific stakeholder concerns in Europe that E-SOP will address include the impact on drinking water supplies and quality, air quality, noise, wastewater and solid wastes, greenhouse gas emissions, truck traffic, and surface disturbance. E-SOP will also address the general public's and policymaker's need for comprehensive and transparent information on the benefits and risks associated with developing these resources. There are significant opportunities to provide technical, training, demonstration, and outreach support to stakeholders and industry.

\section{UNBIASED OPINION-FORMING}

Although long experience with individual technologies used in shale gas production exists, more research and development is needed towards environmentally friendlier shale gas production. This need is emphasised by reports in the media about environmental concerns. Issues under scrutiny include induced seismicity, leakage of gas through casing into aquifers, the potential toxicity of fluids used for hydraulic fracturing and the disposal of fluids returning to the surface. However, the opinions on environmental risks diverge strongly: risks are minor and controllable according to industry, while environmental groups often claim the opposite.

With the Shale Gas Information Platform SHIP (http://www.shale-gas-information-platform.org), GFZ engages in the public discussion of technical and environmental issues related to shale gas exploration and production. SHIP will bring the perspective of science to the discussion, because the pros and cons need to be viewed based on factual argument rather than speculation. SHIP will not only showcase but provides a discussion forum on what is known and what is not yet known about environmental challenges and potential risks. Current scientific results and best practice approaches will be featured by SHIP, building on a network of international experts.

\section{References}

1. IEA, World Energy Outlook (2011)

2. U.S. Energy Information Administration (EIA), International Energy Outlook (2011)

3. European Commission, Energy Roadmap 2050 (2011) 


\section{$2^{\text {nd }}$ European Energy Conference}

4. U.S. Energy Information Administration (EIA), World Shale Gas Resources: An Initial Assessment of 14 Regions Outside the United States (2011)

5. U.S. Environmental Protection Agency (EPA), Final Rule on New Source Performance Standards and National Emission Standards for Hazardous Air Pollutants (2012), http://www.epa.gov/airquality/oilandgas/actions.html

6. R.G. Loucks, R.M. Reed, S.C. Ruppel, D.M. Jarvie, J.Sed. Res., 79 (12), 848-861 (2009)

7. S. Bernard, B. Horsfield, H.-M. Schulz, R. Wirth, A. Schreiber, N. Sherwood, Mar.Pet.Geol., 31, 70-89 (2012) 